of a weed with certain soil conditions, its possession of poisonous or other special properties, as well as the best methods for its eradication, are given in each case.

\section{Salad Crops}

THe growing of salad crops has become a highly specialised business in several parts of England and there seems no reason why the acreage devoted to this branch of horticulture should not be profitably extended. As an aid to growers, whether on a large or small scale, the Ministry of Agriculture has issued an illustrated bulletin (No. 55, H.M. Stationery Office, 1s. 6d. net), from which it is evident that with good management it is possible to have supplies for the market throughout the whole year. Lettuce is quite the most important crop that is included under the term salad, and the best methods for its cultivation in the field, in heated and unheated glasshouses or in frames, are described in detail. Some account is given of the varying methods adopted in different districts and the varieties found to be most satisfactory in each locality, while cultural methods in use in other countries such as America and France are also included. Watercress is another important crop grown for salad purposes. Although little difficulty is experienced in its cultivation, it is essential that the water in which it is grown should be of the highest quality as the industry has suffered considerable harm from cress grown in contaminated streams. Attention to local conditions and markets, and the choice of a suitable variety to meet these requirements, are also needed if the cress-growing is to prove a thoroughly profitable undertaking.

\section{Forest Flora of Syria}

AN expedition under the leadership of Dr. Alexander Eig, head of the Section of Systematic Botany and Ecology at the Hebrew University, Jerusalem, has been examining the forest and other flora of Syria (Science Service, Washington, D.C.). During the tour, the members of the expedition were able to collect valuable material for the herbarium as well as to complete plans for the Syrian Section of the new Botanical Garden at Mount Scopus. The party travelled twice throughout the length and three times across the width of Syria, and were able to fix in a preliminary fashion the line of demarcation between the Mediterranean zone and that of the Urano-Turanic region, the precise boundary between which was previously unknown. An important part of the expedition's work was a study of the forest species of Syria, and the investigations undertaken enabled the principal types of forest species, particularly in the Amanus and Cossus hill regions, to be determined. A study thus begun came to the knowledge of the French Governor of Jebel Druze. The expedition received great assistance from the French Government officials in the mandated territory north of the Sykes-Picot line, and the French Governor has asked Dr. Alexander Eig to advise on the subject of afforesting certain parts of the Jebel Druze region. The determination of the principal Syrian forest types will be, it is said, of considerable importance to the Botanical Garden on Mount Scopus.

\section{Revision of Ordnance Plans}

THE methods adopted in the field revision of the large-scale Ordnance Survey Plans, with some account of earlier methods, are described and explained in detail in a pamphlet by Capt. J. C. T. Willis ("An Outline of the History and Revision of the 25-inch Ordnance Survey Plans". H.M. Stationery Office. 28. 6d.). The revision in the field is carried out by methods of prolongation and intersection but new detail must be 'hung' on to the original survey and not on to matter added at a previous revision. The use of specially selected points on the original survey has been abandoned and the equal reliability of all the original detail is accepted. The newest development adopted to counteract the liability of errors in redrawing the revised sheet entails the use of 'coated' paper at that stage. This paper permits all old detail to be expunged chemically, without affecting the surface of the paper beneath. Then it is found possible to avoid the redrawing of old detail, which involves a saving in accuracy as well as in time. A method of partial revision has had to be adopted in the centres of town and cities on the ground of economy. This neglects minor alterations in back premises while concentrating on the alignment and position of street fronts. The pamphlet contains a number of practical examples of revision, illustrated by charts, and discusses the kind of errors the surveyor may make.

Weather Maps showing Typical Distributions of Pressure

A PAMPHLET has been produced (Air Ministry : Meteorological Office. Examples of Weather Maps showing Typical Distributions of Pressure. (M.O. 237, second edition.) Pp. 8. (London: H.M. Stationery Office, 1932.) $3 d$. net.) to meet the needs of those schools where another publication prepared by the authority of the Meteorological Committee entitled "The Weather Map", which forms an introduction to modern meteorology, is used as a textbook for the teaching of elementary meteorology. The latter work appeared a little more than two years ago (see NATuRE, 126. 755, Nov. 15; 1930). Being a comparatively expensive production (price 3s. net, compared with $3 d$. net in the case of the pamphlet under notice), it was regarded as unsuitable for distribution to individual pupils and accordingly six of the most important illustrative synoptic weather charts have here been selected from it so that pupils would be able with the pamphlet in front of them to follow the explanations of a teacher using "The Weather Map" as a textbook. The six figures selected are those numbered 9, 18, 21, 22,23 and 24 in the textbook, and give typical examples of a depression, anticyclone, secondary depression, V-shaped depression, wedge and col. There is no explanatory matter beyond a paragraph describing the weather corresponding with the various letters that appear on the map (the Beaufort weather notation is used), the method of showing the speed and direction of the wind, the temperature, andby means of isobars for 4 millibar steps-the dis. tribution of pressure. The two publications, both

No. 3296, VoL. 130] 